\title{
УГОЛОВНО-ПРОЦЕССУАЛЬНОЕ РЕГУЛИРОВАНИЕ ИЗЪЯТИЯ ЭЛЕКТРОННЫХ НОСИТЕЛЕЙ И КОПИРОВАНИЯ СОДЕРЖАЩЕЙСЯ НА НИХ ИНФОРМАЦИИ.
}

\author{
Макарова Юлия Витальевна, \\ Студентка Оренбургского института (филиала) \\ Университета имени О.Е.Кутафина (МГЮА), \\ г.Оренбург
}

\begin{abstract}
Аннотация. В статье анализируются проблемные вопросы, связанные с изъятием электронных носителей информации в ходе производства следственных действий, копированием с них информации, а также сопутствующие изменения, происходящие в следственной практике в связи с введением статьи 164.1 в Уголовно- процессуальный кодекс РФ.

Annotation. The article analyzes the problematic issues related to the seizure of electronic media during the production of investigative actions, copying information from them, as well as related changes taking place in investigative practice in connection with the introduction of Article 164.1 into the Criminal Procedure Code of the Russian Federation.

Ключевые слова: электронные носители информации, копирование и изъятие информации, хранение информации, доказательства.
\end{abstract}

Keywords: electronic media, copying and seizure of information, storage of information, evidence.

Развитие информационно- телекоммуникационных технологий существенно улучшило жизнь современного общества. Сбор, хранение , распространение информации - неотъемлемый процесс использования информационных технологий. При этом, несмотря на все более частое обращения следователя к пострению доказательственного материала с использованием электронных носителей информации и их содержимого, в уголовно-процессуальном законодательстве существует ряд проблемных вопросов. Изучение нормы ст. 164.1 УПК РФ показывает, что некоторые положения, в частности о копировании информации в ходе изъятия электронного носителя и об участии специалиста, ранее нашли своё закрепление в части 9.1 статьи 182 и части 3.1. статьи 183 УПК РФ. Вместе с тем, появились другие правовые положения, характеризующие изъятие электронного носителя. Прежде всего можно отметить преимущества, которые получили юридические лица и предприниматели. Изъятие электронных носителей может привести к приостановлению законной деятельности юридических лиц или индивидуальных предпринимателей, в связи с чем в ходе расследования отдельных преступлений, совершенных в сфере предпринимательской деятельности, не допускается изъятие электронных носителей информации. Перечень этих уголовно-наказуемых деяний содержится в части 4.1. ст. 164 УПК РФ. В части 1 ст. 164.1 УПК РФ законодатель указал исключительные случаи, когда не допускается изъятие электронного носителя. Однако толкования этих случаев отсутствует . Можно предположить, что нововведения появились в нарушение должного системного единства уголовно-процессуальных норм. Поэтому , необходим анализ каждого случая . [1]

Первый случай законодательно определен выражением - «когда вынесено постановление о назначении судебной экспертизы электронного носителя информации». Вынесение постановления о назначении судебной экспертизы электронного носителя информации до его изъятия нецелесообразно по следующим основаниям. Во-первых, обеспечивая права участников уголовного процесса по ч. 3 ст. 195 и ст. 198 УПК РФ, они должны быть ознакомлены с постановлением о назначении судебной экспертизы и могут заявить дополнительные вопросы эксперту. Во-вторых, в распоряжение эксперта предоставляются материалы (в частности электронный носитель информации) для исследования и дачи заключения по ним. Для представления электронного носителя эксперту и его указания в соответствующем постановлении необходимо знать его вид, марку, идентификатор и иные индивидуальные и специфические характеристики. Возникает логичный вопрос: каким образом можно указать материал - электронный носитель информации до момента его изъятия? По сути законодатель нарушает логическую и взаимосвязанную друг с другом последовательность действий. Без материалов, в частности электронного носителя информации, невозможно назначение судебной экспертизы как этапа комбинированного сложного процессуального средства доказывания - производства судебной экспертизы, регламентированного главой 27 УПК РФ.

Содержание ч. 2 ст. 164.1 УПК РФ обязывает должностных лиц производить изъятие электронных носителей информации в ходе производства следственных действий. Однако непонятно , какие следственные действия имел в виду составитель уголовно-процессуальной нормы. Появляется еще один вопрос, связанный с отсутствием в ч. 2 ст. 29 и ч. 1 ст. 165 УПК РФ указания на требование о производстве изъятия электронных носителей информации по судебному постановлению. Указанные правовые положения, регламентирующие судебный контроль в досудебном уголовном производстве, в частности за производством следственных 
действий, затрагивающих конституционные права гражданина, не предполагают получение судебного разрешения для изъятия электронных носителей информации.[2] Отсюда можно предположить, что ч. 4.1 ст. 164 и ст. 164.1 УПК РФ применяются для изъятия электронного носителя, производимого во время производства следственных действий, требующих получение судебного разрешения. Но в таком случае при осмотре места происшествия, проверке показаний на месте, следственном эксперименте и иных следственных действиях, не требующих судебного постановления, по преступлениям, указанным в ч. 4.1. ст. 164 УПК РФ, изъятие электронных носителей не допускается. Однако в ходе производства указанных следственных действий также может возникнуть необходимость изъятия электронных носителей информации.

Изучение и исследование информации, содержащейся на электронном носителе, осуществляется в ходе осмотра электронного носителя, по результатам которого принимается решение о копировании информации и о наличии обстоятельств, предусмотренных в п. 3 ч. 1 ст. 164.1 УПК РФ. Поэтому считаю необходимым расширить перечень видов осмотра электронного носителя информации, закрепив его в ст. 176 в предлагаемой мною части.

Представляется, что ст. 176 УПК РФ следует дополнить частью 1.1. следующего содержания:

«1.1. Осмотр электронных носителей информации производится с целью:

а) обнаружения информации, которая может быть использована для совершения новых преступлений;

б) решения вопроса о копировании информации с электронного носителя; г) установления обстоятельств, имеющих значение для уголовного дела;

д) установления полномочий на хранение и использование информации, содержащейся на электронном носителе».

Также необходимо дополнить ст. 177 УПК РФ частью 7 следующего содержания: «7. Осмотр информации, содержащейся в электронном носителе, производится только по судебному решению» и дополнить часть 2 ст. 29 УПК РФ пунктом 14 следующего содержания: « 14) об осмотре информации, содержащейся в электронном носителе »

Исследование вопросов изъятия электронных носителей информации в ходе производства следственных действий позволяет сделать вывод о том, что в следственно-судебной практике могут возникнуть проблемы применения ст. 164.1 УПК РФ. По моему мнению, содержание указанной статьи требует уточнения, совершенствования, более четкой и понятной для субъектов уголовной юрисдикции и других участников уголовного процесса процедуры.

С учетом изменений ст. 164.1. будет изложена в следующей редакции: «Статья 164.1. Особенности изъятия электронных носителей информации и копирования с них информации при производстве следственных действий.

1. Электронные носители информации изымаются в ходе следственных действий с участием понятых и с участием специалиста в случаях, предусмотренных статьей 168 УПК РФ.

2. Специалистом по просьбе следователя в ходе производства следственного действия может осуществляться изъятие путем копирования. В протоколе следственного действия должны быть указаны технические средства, примененные при осуществлении копирования информации, порядок их применения, электронные носители информации, к которым эти средства были применены, и полученные результаты. К протоколу прилагаются электронные носители информации, содержащие информацию, скопированную с других электронных носителей информации в ходе производства следственного действия. 3. По ходатайству законного владельца информации, содержащейся на изымаемом электронном носителе информации, специалистом с участием понятых осуществляется копирование информации на другой электронный носитель, предоставленный владельцем информации

Список использованных источников:

1. Батура Т.В., Мурзин Ф.А., Семин Д.Ф.Облачные технологии: основные модели, концепции и тенденции развития// Программные продукции и системы . 2014. № 3. С. 1-22.

2.Гаврилин Ю.В. Электронные носители информации в уголовном судопроизводстве // Тр. Академии управления МВД России 2017. № 4. С. 45-47.

3.Межгосударственный стандарт. Единая система конструкторской документации. Электронные документы. Общие положения ГОСТ2.051-2013.// Доступ из СПС “ Консультант ПЛЮС” (Дата обращения: 29.11.2021) 